Abstracta Iranica Abstracta Iranica

Revue bibliographique pour le domaine irano-aryen

Volume 32-33 | 2013

Comptes rendus des publications de 2009-2010

\title{
I. Afshar, T. Daryaee (eds.). Scholars and Humanists. Iranian Studies in W. B. Henning and S. H. Taqizadeh Correspondence 1937-1966
}

\section{Rika Gyselen}

\section{(2) OpenEdition}

1 Journals

\section{Édition électronique}

URL : http://journals.openedition.org/abstractairanica/40136

DOI : 10.4000/abstractairanica.40136

ISSN : 1961-960X

Éditeur :

CNRS (UMR 7528 Mondes iraniens et indiens), Éditions de l'IFRI

Édition imprimée

Date de publication : 1 décembre 2013

ISSN : 0240-8910

Référence électronique

Rika Gyselen, «I. Afshar, T. Daryaee (eds.). Scholars and Humanists. Iranian Studies in W. B. Henning and S. H. Taqizadeh Correspondence 1937-1966», Abstracta Iranica [En ligne], Volume 32-33 | 2013, document 210, mis en ligne le 01 juillet 2016, consulté le 26 septembre 2020. URL : http:// journals.openedition.org/abstractairanica/40136; DOI : https://doi.org/10.4000/abstractairanica. 40136

Ce document a été généré automatiquement le 26 septembre 2020.

Tous droits réservés 


\title{
I. Afshar, T. Daryaee (eds.). Scholars and Humanists. Iranian Studies in W. B. Henning and S. H. Taqizadeh Correspondence 1937-1966
}

\author{
Rika Gyselen
}

\section{RÉFÉRENCE}

I. Afshar, T. Daryaee (eds.). Scholars and Humanists. Iranian Studies in W. B. Henning and

S. H. Taqizadeh Correspondence 1937-1966. Costa Mesa, Mazda Publishers, 2009. 318 p.

1 Ce volume intéressera tous ceux qui consultent régulièrement les publications de W. B. Henning et de S. H. Taqizadeh. Leurs échanges épistolaires entre les années 1937 et 1966 jettent non seulement une lumière sur leurs rapports professionnels, mais également sur leur personnalité respective. De cette correspondance ressort aussi le rôle inestimable qu'a joué S. H. Taqizadeh en tant que sénateur et ambassadeur, dans la propagation des études iraniennes.

\section{AUTEURS}

RIKA GYSELEN

CNRS/Mondes iranien et indien, Paris 